\title{
Pengaruh keterlibatan orang tua, perilaku guru, dan motivasi belajar terhadap prestasi belajar matematika siswa
}

\author{
Abdoulaye Fane ${ }^{1} *$, Sugito Sugito ${ }^{2}$ \\ ${ }^{1}$ University of Letters and Human Sciences of Bamako. Bamako, Mali. \\ ${ }^{2}$ Program Pascasarjana, Universitas Negeri Yogyakarta. Jalan Colombo No. 1, Yogyakarta, 55281, Indonesia \\ Email: abdoulayefane2007@yahoo.fr \\ * Corresponding Author
}

\section{ARTICLE INFO}

\section{Article history}

Received: 11 August. 2017;

Revised: 16 December 2017;

Accepted: 3 August 2019

\section{Keywords}

keterlibatan orang tua; perilaku guru; motivasi belajar; prestasi belajar; parental involvement; teacher behavior; motivation; mathematics achievement

\begin{abstract}
Penelitian ini bertujuan untuk untuk mendeskripsikan pengaruh keterlibatan orang tua, perilaku guru, dan motivasi belajar baik terhadap prestasi belajar mata pelajaran matematika siswa kelas X SMA. Penelitian ini merupakan penelitian expost facto. Populasi dalam penelitian ini adalah siswa kelas X MIPA SMA Negeri 4 Yogyakarta, Indonesia, tahun ajaran 2016/2017. Sampel penelitian sejumlah 121 siswa ditentukan menggunakan simple random sampling technique. Pengumpulan data menggunakan studi dokumen hasil belajar matematika siswa dan angket yang telah dibuktikan validitas serta diestimasi reliabilitasnya. Teknik analisis data yang digunakan adalah analisis regresi ganda. Hasil penelitian menunjukkan bahwa: (1) terdapat pengaruh positif dan signifikan masing-masing variabel yaitu keterlibatan orang tua, perilaku guru, motivasi belajar terhadap prestasi belajar matematika siswa kelas X SMA Negeri 4 Yogyakarta; dan (2) secara bersamaan (simultan) variabel keterlibatan orang tua, perilaku guru, dan motivasi belajar berpengaruh positif dan signifikan terhadap prestasi belajar matematika siswa kelas X SMA Negeri 4 Yogyakarta.
\end{abstract}

This research aimed to describe the effect of parental involvement, teacher behavior, learning motivation on students' mathematics achievement in grade $X$ of Junior High School. This research was ex post facto research. The population was grade X students of SMA Negeri 4 Yogyakarta, Indonesia in the 2016/2017 academic year. The sample of 121 students was established using the simple random sampling technique. The data were collected through documents study of students' mathematics achievement results and using a questionnaire that had been proven its validity and estimated its reliability. The data analysis technique used is linear and multiple regression. The research finding shows that (1) there is a positive and significant effect of each variable namely parental involvement, teacher behavior, learning motivation on mathematics achievement of grade X students of SMA Negeri 4 Yogyakarta; and (2) parental involvement, teacher behavior, and learning motivation simultaneously provide a positive and significant effect on mathematics achievement of grade X students of SMA Negeri 4 Yogyakarta.

This is an open access article under the CC-BY-SA license.

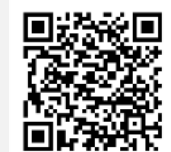

How to Cite: Fane, A., \& Sugito, S. (2019). Pengaruh keterlibatan orang tua, perilaku guru, dan motivasi belajar terhadap prestasi belajar matematika siswa. Jurnal Riset Pendidikan Matematika, 6(1), 53-61. doi:https://doi.org/10.21831/jrpm.v6i1.15246

\section{PENDAHULUAN}

Kemajuan suatu negara salah satunya ditentukan oleh penguasaan terhadap teknologi. Untuk itu, agar suatu negara dapat lebih maju, diperlukan Sumber Daya Manusia (SDM) yang menguasai 
teknologi. Untuk menguasai teknologi tersebut maka SDM yang ada perlu dibekali dengan berbagai ilmu pengetahuan, salah satunya ilmu pengetahuan di bidang matematika. Tella (2007) berpandangan bahwa "one subject that cuts across all the sciences is the mathematics. Today, mathematical methods pervade literally every field of human endeaveour and play a fundamental role in economic development of a country". Sementara itu, Donovan dan Bransford (2005, p. 221) berpendapat bahwa "mathematics is a constantly evolving field that is far from cut and dried. It involves systematic pattern finding and continuing invention". Dari kedua pendapat tersebut dapat dipahami bahwa matematika sangat berperan penting untuk kemajuan sains serta secara tidak langsung ikut berkontribusi terhadap kemajuan suatu negara.

Mengingat pentingnya peranan matematika, maka matematika menjadi salah satu mata pelajaran wajib yang diselenggarakan oleh lembaga pendidikan. Dalam suatu lembaga pendidikan pencapaian proses pembelajaran dapat dilihat dari prestasi belajar yang dicapai oleh siswa. Sebagaimana yang dikemukakan oleh Hamalik (2010, p. 159) bahwa prestasi belajar adalah tingkat hasil belajar yang dicapai oleh siswa setelah melakukan kegiatan belajar dalam upaya mencapai tujuan pembelajaran yang telah ditetapkan. Prestasi yang ingin dicapai oleh siswa pada hasil pembelajaran matematika merupakan pengetahuan siswa tersebut tentang konten matematika yang telah dipelajari. Prestasi belajar selain sebagai hasil dari proses pendidikan, juga menggambarkan sejauh mana siswa, guru atau lembaga telah mencapai tujuan pendidikan (Paulpandi \& Govindharaj, 2017). Dengan demikian prestasi belajar juga dapat dijadikan sebagai rujukan untuk mengevaluasi ketercapaian tujuan pendidikan.

Pencapaian prestasi belajar dapat lebih optimal jika seorang siswa merasa termotivasi untuk meningkatkan prestasi belajar yang telah diraih sebelumnya. Prestasi belajar yang optimal juga didukung oleh keterlibatan siswa secara aktif dalam aktivitas pembelajaran (Fung, Tan, \& Chen, 2018). Namun pada kenyataannya, prestasi belajar matematika masih belum memenuhi harapan, termasuk di Indonesia. Berdasarkan survei Trends in International Mathematics and Science Study (TIMSS) pada tahun 2011 diketahui bahwa prestasi matematika siswa Indonesia berada pada urutan ke-44 dari 49 negara dengan skor rata-rata 397 (Mullis, Martin, Foy, \& Arora, 2012), sedangkan survei yang dilakukan oleh Organisation for Economic Co-operation and Development (OECD) pada tahun 2015 menggunakan tes Programme for International Student Assesment (PISA) hasilnya menunjukkan bahwa prestasi matematika Indonesia berada pada peringkat 69 dari 76 negara yang mengikuti studi PISA (OECD, 2016). Berdasarkan kedua hasil studi internasional tersebut, jelas bahwa di level internasional prestasi matematika siswa di Indonesia masih tertinggal. Data Ujian Nasional (UN) tahun 2016 juga dapat digunakan untuk melihat rendahnya prestasi belajar siswa. Pada tingkat nasional untuk jenjang SMA program IPA, diketahui bahwa rata-rata nilai matematika paling turun jika dibandingkan dengan mata pelajaran lainnya, yaitu dari rata-rata skor 59,17 pada tahun 2015 menjadi 53,03 di tahun 2016 (Badan Standar Nasional Pendidikan, 2015, 2016).

Berdasarkan data-data yang telah dikemukakan tersebut dapat disimpulkan bahwa prestasi matematika siswa Indonesia sangat rendah. Rendahnya prestasi matematika di Indonesia juga didasari oleh masih rendahnya prestasi belajar matematika di setiap daerah di Indonesia. Dari data tersebut dapat dinyatakan bahwa prestasi belajar matematika di Indonesia masih belum memuaskan. Dalam lingkup regional seperti di Kota Yogyakarta, jika mengacu pada laporan hasil UN tahun 2015 dan 2016 (Puspendik, 2015, 2016), terlihat jika rata-rata nilai UN matematika juga mengalami penurunan. Hal tersebut jelas mengindikasikan bahwa prestasi belajar matematika di Kota Yogyakarta juga masih perlu ditingkatkan. Rendahnya prestasi belajar matematika mengindikasikan ada sesuatu yang kurang tepat dan belum optimal dalam pembelajaran matematika di sekolah. Rendahnya prestasi belajar siswa dapat disebabkan beberapa faktor, contohnya adalah keterlibatan orang tua terhadap prestasi belajar siswa belum memberikan motivasi yang kuat kepada siswa, perilaku guru, dan motivasi belajar siswa yang rendah.

Salah satu yang termasuk faktor eksternal yang menentukan prestasi belajar siswa adalah keluarga khususnya keterlibatan orang tua (Komsi, Hambali, \& Ramli, 2018). Orang tua sangat berperan dalam perkembangan dan pendidikan anak (Gonida \& Cortina, 2014). Oleh karena itu keterlibatan yang diberikan oleh orang tua sangat berpengaruh pada prestasi belajarnya di sekolah. Dengan adanya keterlibatan khususnya dari orang tua, maka peserta didik menjadi lebih terkontrol dan mempunyai dorongan tersendiri untuk meraih prestassi belajar matematika yang lebih baik. Seperti yang telah dikemukakan Wirowidjojo (Slameto, 2010, p. 61) bahwa "keluarga/orang tua merupakan lembaga utama, pertama dan yang paling dekat dengan anak". Pengertian, penerimaan, pemahaman, perhatian, 
serta bantuan orang tua menjadi sangat berarti bagi anak untuk mengarahkan kehidupan dan pencapaian prestasi belajar matematika. Dengan begitu keterlibatan orang tua dalam belajar anaknya merupakan salah satu faktor terpenting untuk membangun sukses belajar. Namun pada kenyataanya masih ada orang tua yang belum bisa melibatkan diri secara maksimal dalam perkembangan anaknya khususnya dalam hal yang mendukung peningkatan prestasi belajarnya. Orang tua yang kurang melibatkan diri dalam pendidikan anaknya tersebut disebabkan oleh berbagai macam faktor. Salah satu diantaranya yaitu sibuknya aktivitas atau pekerjaan orang tua, sehingga menyebabkan kurangnya keterlibatan yang diberikan oleh orang tua kepada anaknya (Jay, Rose, \& Simmons, 2018). Kurangnya keterlibatan orang tua tersebut dapat menyebakan anak-anak menjadi malas, acuh tak acuh, dan kurangnya motivasi atau minat belajar (Silinskas \& Kikas, 2019). Dengan demikian, keterlibatan dari orang tua merupakan hal penting dalam menentukan baik-buruknya prestasi belajar matematika seorang anak.

Selain keterlibatan orang tua salah satu faktor eksternal lain yang menentukan prestasi belajar siswa adalah perilaku guru. Perilaku adalah kegiatan manusia itu sendiri yang memiliki berbagai macam arti. Kaitannya dengan perilaku, Mehdipour dan Balaramulu (2013) mengatakan bahwa "behaviour can be defined as a description of the observable outcome of teacher and student performance in different activities of institutions. Behaviour may be positive or negative and effective or ineffective". Guru yang mempunyai perilaku yang baik dapat memberikan ucapan yang penuh dengan motivasi dengan semangat sehingga membuat siswa merasa yakin bahwa dirinya mampu mengatasi segala kesulitan dalam menyelesaikan tugas sekaligus membantu meningkatkan kinerjanya. Sedangkan ketika seorang guru menyampaikan pelajaran dengan penuh tekanan dan kaku maka siswa dapat merasa kurang nyaman dengan guru tersebut. Hal tersebut dapat menyebabkan keyakinan dan kinerja siswa untuk mengatasi kesulitan dan menyelesaikan tugas menjadi berkurang. Untuk itu, diperlukan seorang guru yang memahami kondisi fisik maupun psikis siswa-siswanya, karena dengan begitu akan lebih mudah bagi guru untuk memilih cara yang tepat untuk menyampaikan materi pelajaran. Dengan demikian, perilaku guru dalam proses pembelajaran sangat berpengaruh terhadap prestasi belajar siswa. Kaitannya dengan hal itu, Mehdipour dan Balaramulu (2013) berpandangan bahwa "the influence of teacher's behavior plays an important role in the academic achievement of students. A teacher has to display exceptional empathy, persistence, diligence, sincerity, research orientation, honesty and flexibility as a person". Dari pendapat tersebut dapat dipahami bahwa perilaku guru dalam mengajar sangat penting untuk mendukung prestasi akademik siswa.

Selain faktor eksternal, salah satu yang termasuk faktor internal yang menentukan prestasi belajar siswa adalah motivasi belajar. Motivasi belajar dimaksudkan sebagai suatu kondisi psikis yang mendorong siswa untuk melakukan aktivitas guna mencapai tujuan yaitu hasil belajar yang maksimal. Dengan begitu siswa yang memiliki keinginan dan motivasi untuk berhasil tentu cenderung mempunyai sikap positif, yang dapat memacu siswa untuk meraih hasil belajar yang lebih baik (Rivai \& Murni, 2016). Motivasi merupakan salah satu faktor yang ikut menentukan tinggi rendahnya prestasi yang akan dicapai oleh siswa (Kurniawan \& Wustqa, 2014). Dengan memiliki motivasi yang kuat, maka individu tersebut akan berusaha keras untuk mencapai tujuannya. Motivasi dalam diri individu berbeda-beda, ada yang memiliki motivasi kuat, ada yang bermotivasi sedang dan ada yang lemah, sehingga faktor motivasi ini merupakan salah satu faktor yang memiliki peran penting terhadap intensitas belajar siswa sehingga menentukan prestasi belajarnya.

Berdasarkan latar belakang dan kajian teori yang telah dikemukakan sebelumnya, maka penelitian ini secara spesifik bertujuan untuk mendeskripsikan seberapa besar pengaruh masing-masing variabel yaitu keterlibatan orang tua, perilaku guru, dan motivasi belajar terhadap prestasi belajar matematika siswa dan seberapa besar pengaruh variabel keterlibatan orang tua, perilaku guru, dan motivasi belajar secara bersama-sama (simultan) terhadap prestasi belajar matematika siswa.

\section{METODE}

Pendekatan yang digunakan dalam penelitian ini adalah kuantitatif dengan jenis expost facto. Penelitian expost facto merupakan penelitian di mana variabel-variabel bebas telah terjadi ketika peneliti mulai dengan pengamatan variabel terikat dalam suatu penelitian (Sukardi, 2013). Waktu penelitian dilakukan pada bulan Maret-Mei 2017 di SMA Negeri 4 Yogyakarta. Penelitian ini dilakukan di SMA Negeri 4 Yogyakarta pada Tahun Ajaran 2016-2017 yang beralamatkan di Jalan Magelang, Kelurahan 
Karangwaru Lor, Kecamatan Tegalrejo, Kota Yogyakarta, Provinsi Daerah Istimewa Yogyakarta. Indonesia.

Populasi dalam penelitian ini adalah seluruh siswa kelas SMA Negeri 4 Yogyakarta pada Tahun Pelajaran 2016/2017. Teknik pengambilan sampel menggunakan simple random sampling, yaitu sampel yang diambil secara acak tanpa memperhatikan strata yang ada dalam populasi tersebut (Sugiyono, 2015, p. 118). Sampel dalam penelitian ini berjumlah 121 siswa. Penentuan jumlah sampel berdasarkan rumus Slovin pada taraf kesalahan 5\%.

Teknik pengumpulan data menggunakan angket dan studi dokumen. Sebelum digunakan, angket terlebih dahulu divalidasi. Validasi melibatkan pendapat dari ahli (judgment experts) dan dilakukan perbaikan terhadap angket berdasarkan masukan dari ahli. Setalah divalidasi, angket diujicobakan untuk mengestimasi reliabilitasnya. Estimasi reliabilitas angket menggunakan rumus Alpha Cronbach. Instrumen dapat dikatakan reliabel jika koefesien Alpha Cronbach lebih besar dari 0,6 (Siregar, 2010, p. 175). Mengacu pada pendapat tersebut maka instrumen angket telah memenuhi kriteria reliabel. Studi dokumen bertujuan untuk memperoleh data prestasi belajar siswa. Dokumen tersebut diperoleh langsung dari guru yang mengajar mata pelajaran matematika pada kelas-kelas yang siswanya menjadi sampel penelitian.

Teknik analisis yang digunakan adalah analisis regresi ganda. Dalam penelitian ini analisis regresi ganda bertujuan untuk mencari pengaruh antara variabel variabel bebas keterlibatan orang tua $\left(\mathrm{X}_{1}\right)$, perilaku guru $\left(\mathrm{X}_{2}\right)$, dan motivasi belajar $\left(\mathrm{X}_{3}\right)$ terhadap variabel terikat yaitu prestasi belajar matemamatika siswa (Y). Sebelum analisis regresi dilakukan, terlebih dahulu dilakukan uji prasyarat analisis regresi, yaitu uji galat berdistribusi normal, uji linieritas, uji multikolinieritas dan uji heteroskedastisitas.

\section{HASIL DAN PEMBAHASAN}

\section{Hasil}

Uji Prasyarat Analisis

Pengujian prasyarat analisis dilakukan sebelum melakukan analisis regresi linier berganda. Prasyarat yang diuji dalam penelitian ini meliputi uji normalitas, uji linieritas, uji multikolinieritas dan uji heteroskedastisitas dan pengujiannya menggunakan bantuan program SPSS 13.00 for Windows. Hasil uji prasyarat analisis disajikan berikut ini.

\section{Uji Normalitas}

Uji normalitas bertujuan untuk menunjukkan apakah galat untuk masing-masing variabel berdistribusi normal. Hasil uji normalitas untuk masing-masing variabel penelitian tersebut disajikan pada Tabel 1.

Tabel 1. Hasil Uji Normalitas

\begin{tabular}{lccc}
\hline & Variabel & Sig & Ket. \\
\hline Keterlibatan Orang Tua & 0,821 & Normal \\
Perilaku Guru & 0,208 & Normal \\
Motivasi Belajar & 0,154 & Normal \\
Prestasi Belajar & 0,109 & Normal \\
\hline
\end{tabular}

Hasil uji normalitas untuk masing-masing variabel pada Tabel 1 menunjukkan bahwa semua variabel mempunyai nilai signifikansi lebih besar dari 0,05 pada (sig > 0,05), sehingga dapat disimpulkan bahwa sebaran galat untuk masing-masing variabel penelitian berdistribusi normal.

\section{Uji Linieritas}

Uji prasyarat linieritas bertujuan untuk menunjukkan apakah masing-masing variabel bebas memiliki hubungan linier terhadap variabel terikat. Hasil rangkuman uji linieritas dalam penelitian ini disajikan pada Tabel 2. Berdasarkan hasil uji linieritas pada Tabel 2 dapat diketahui bahwa semua variabel memiliki nilai signifikansi yang lebih besar dari 0,05 ( $\mathrm{sig}>0,05)$, hal ini menunjukkan bahwa semua variabel bebas penelitian memiliki hubungan linier dengan variabel terikat. 
Jurnal Riset Pendidikan Matematika, 6 (1), 2019 - 57

Abdoulaye Fane, Sugito Sugito

Tabel 2. Hasil Uji Linieritas

\begin{tabular}{lccl}
\hline & Variabel & Sig. & Ket. \\
\hline Keterlibatan Orang Tua & & 0,175 & Linier \\
Perilaku Guru & & 0,067 & Linier \\
Motivasi Belajar & & 0,095 & Linier \\
\hline
\end{tabular}

\section{Uji Multikolinieritas}

Hasil uji multikolinieritas untuk model regresi pada penelitian ini disajikan pada Tabel 3.

Tabel 3. Hasil Uji Multikolinieritas

\begin{tabular}{lccl}
\hline \multicolumn{1}{c}{ Variabel } & Tolerance & VIF & Kesimpulan \\
\hline Keterlibatan Orang Tua & 0,712 & 1,405 & Tidak terjadi multikolinieritas \\
Perilaku Guru & 0,658 & 1,521 & Tidak terjadi multikolinieritas \\
Motivasi Belajar & 0,623 & 1,604 & Tidak terjadi multikolinieritas \\
\hline
\end{tabular}

Dari Tabel 3 terlihat bahwa semua variabel mempunyai nilai toleransi di atas 0,1 dan nilai VIF di bawah 10, sehingga dapat disimpulkan bahwa model regresi pada penelitian ini tidak terjadi multikolinieritas.

\section{Uji Heteroskedastisitas}

Hasil uji heteroskedastisitas dilakukan untuk menunjukkan apakah ragam galat konstan dari satu pengamatan ke pengamatan lainnya. Hasil uji heteroskedastisitas untuk untuk masing-masing variabel bebad pada penelitian ini disajikan pada Tabel 4.

Tabel 4. Hasil Uji Heteroskedastisitas

\begin{tabular}{lcl}
\hline \multicolumn{1}{c}{ Variabel } & Sig. & Kesimpulan \\
\hline Keterlibatan Orang Tua & 0,942 & Tidak terjadi heteroskedastisitas \\
Perilaku Guru & 0,998 & Tidak terjadi heteroskedastisitas \\
Motivasi Belajar & 0,495 & Tidak terjadi heteroskedastisitas \\
\hline
\end{tabular}

Tabel 4 menunjukkan bahwa semua variabel mempunyai nilai signifikansi lebih besar dari 0,05 sehingga dapat disimpulkan bahwa tidak terjadi heteroskedastisitas untuk masing-masing variabel.

Pengujian Hipotesis

Pada penelitian ini analisis regresi berganda yang dilakukan dengan menggunakan bantuan program SPSS 13.00 for windows. Rangkuman hasil analisis regresi berganda disajikan pada Tabel 5.

Tabel 5. Rangkuman Hasil Analisis Regresi Berganda

\begin{tabular}{lcccc}
\hline \multicolumn{1}{c}{ Variabel } & Koefisien Regresi (b) & t-hitung & Sig. & Ket. \\
\hline Keterlibatan Orang Tua & 0,196 & 2,635 & 0,010 & Signifikan \\
Perilaku Guru & 0,344 & 4,446 & 0,000 & Signifikan \\
Motivasi Belajar & 0,350 & 4,401 & 0,000 & Signifikan \\
Konstanta $=59,893$ & & & & \\
$\mathrm{R}^{2}=0,539$ & & & & \\
F hitung $=45,626$ & & & & \\
Sig. $=0,000$ & & & & \\
\hline
\end{tabular}

Berdasarkan Tabel 5, hasil uji $t$ untuk variabel keterlibatan orang tua diperoleh nilai $t$ hitung sebesar 2,635 dengan tingkat signifikansi 0,010. Karena nilai signifikansi lebih kecil dari 0,05 $(0,010<$ $0,05)$, dan koefisien regresi mempunyai nilai positif sebesar 0,196 , maka hipotesis yang menyatakan bahwa terdapat pengaruh positif dan signifikan keterlibatan orang tua terhadap prestasi belajar matematika siswa kelas X SMA Negeri 4 Yogyakarta tahun ajaran 2016/2017 terbukti.

Tabel 5 juga menunjukkan hasil uji $t$ untuk variabel perilaku guru diperoleh nilai $t$ hitung sebesar 4,446 dengan tingkat signifikansi 0,000. Karena nilai signifikansi lebih kecil dari 0,05 $(0,000<0,05)$, dan koefisien regresi mempunyai nilai positif sebesar 0,344 , maka hipotesis yang menyatakan bahwa terdapat pengaruh positif dan signifikan perilaku guru terhadap prestasi belajar matematika siswa kelas X SMA Negeri 4 Yogyakarta tahun ajaran 2016/2017 juga terbukti. 
Dari Tabel 5 juga dapat dilihat bahwa hasil uji $t$ untuk variabel motivasi belajar diperoleh nilai $t$ hitung sebesar 4,401 dengan tingkat signifikansi 0,000. Karena nilai signifikansi lebih kecil dari 0,05 $(0,000<0,05)$, dan koefisien regresi mempunyai nilai positif sebesar 0,350 , maka hipotesis yang menyatakan bahwa terdapat pengaruh positif dan signifikan motivasi belajar terhadap prestasi belajar matematika siswa kelas X SMA Negeri 4 Yogyakarta tahun ajaran 2016/2017 juga terbukti.

Selanjutnya, untuk mengetahui pengaruh ketiga variabel bebas secara simultan terhadap prestasi belajar matematika siswa, maka dilakukan uji $F$. Dari hasil pengujian diperoleh nilai $F$ hitung sebesar 45,626 dengan signifikansi sebesar 0,000. Oleh karena nilai signifikansi lebih kecil dari 0,05 $(0,000<$ $0,05)$, dengan demikian hipotesis yang menyatakan bahwa terdapat pengaruh keterlibatan orang tua, perilaku guru, dan motivasi belajar secara bersama-sama terhadap prestasi belajar matematika siswa kelas X SMA Negeri 4 Yogyakarta tahun ajaran 2016/2017 terbukti. Selain itu, nilai koefisien determinasi $\left(R^{2}\right)$ untuk model regresi pada penelitian ini yaitu sebesar 0,539 . Hal ini menunjukkan bahwa prestasi belajar matematika dipengaruhi oleh variabel keterlibatan orang tua, perilaku guru, dan motivasi belajar sebesar $53,9 \%$, sedangkan sisanya yaitu sebesar $46,1 \%$ dipengaruhi oleh faktor lain yang tidak termasuk dalam penelitian ini.

\section{Pembahasan}

\section{Pengaruh Keterlibatan Orang Tua terhadap Prestasi Belajar}

Hasil penelitian ini menunjukkan bahwa terdapat pengaruh positif dan signifikan keterlibatan orang tua terhadap prestasi belajar mata pelajaran matematika siswa. Menurut Sutjupto (Slameto, 2010, p. 61) keluarga/orang tua merupakan lembaga utama, pertama dan yang paling dekat dengan anak. Hal itu menjadi terpenting bagi anak. Pengertian, penerimaan, pemahaman, perhatian, serta bantuan orang tua menjadi sangat berarti bagi anak untuk mengarahkan kehidupan dan pencapaian prestasi belajar Matematika. Dengan adanya keterlibatan khususnya dari orang tua, maka peserta didik menjadi lebih terkontrol dan mempunyai dorongan tersendiri untuk meraih prestasi belajar matematika yang lebih baik. Dengan begitu keterlibatan orang tua dalam belajar anaknya merupakan salah satu faktor terpenting untuk membangun sukses belajar.

Keterlibatan orangtua dalam prestasi belajar anaknya akan membawa dampak yang positif terhadap cara belajar anaknya. Hal ini akan membantu anak untuk belajar menjalani proses pendidikan yang berlangsung di sekolah dan di rumah. Orang tua yang telah memiliki wawasan serta pengalaman yang cukup akan memiliki tanggung jawab yang tinggi terhadap pendidikan anaknya. Sebagaimana Schunk, Pintrich, dan Meece (2008) menyimpulkan beberapa bentuk tanggung jawab dan keterlibatan orang tua terhadap pendidikan anak-anaknya antara lain: memenuhi sarana dan prasarana yang dibutuhkan, memperhatikan kegiatan belajar di rumah, memperhatikan kegiatan belajar di sekolah, dan memberikan motivasi.

\section{Pengaruh Perilaku Guru terhadap Prestasi Belajar}

Hasil penelitian ini menunjukkan bahwa terdapat pengaruh positif dan signifikan perilaku guru terhadap prestasi belajar matematika siswa. Temuan tersebut sejalan dengan hasil penelitian (You, Dang, \& Lim, 2016). Hal tersebut disebabkan karena guru yang mempunyai perilaku yang baik dapat memberikan ucapan yang penuh dengan motivasi dengan semangat sehingga membuat siswa merasa yakin bahwa dirinya mampu mengatasi segala kesulitan dalam menyelesaikan tugas sekaligus membantu meningkatkan kinerja. Adapun ketika seorang guru menyampaikan pelajaran dengan penuh tekanan dan kaku maka murid merasa kurang nyaman dengan guru itu dan tentu saja hal tersebut membuat keyakinan dan kinerja murid untuk mengatasi kesulitan dan menyelesaikan tugas menjadi berkurang. Untuk itu, diperlukan guru yang memahami kondisi fisik dan psikis siswa. Dengan demikian perilaku guru dalam proses pembelajaran sangat berpengaruh terhadap prestasi belajar siswa.

\section{Pengaruh Motivasi Belajar terhadap Prestasi Belajar}

Hasil penelitian ini menunjukkan bahwa terdapat pengaruh positif dan signifikan motivasi belajar terhadap prestasi belajar matematika siswa. Hasil ini sesuai dengan hasil penelitian (Kurniawan \& Wustqa, 2014; Muhammad, Bakar, Mijinyawa, \& Halabi, 2015; Tella, 2007), dimana penelitianpenelitian tersebut menunjukkan bahwa motivasi belajar secara signifikan mempengaruhi prestasi akademik siswa. Terkait dengan temuan penelitian itu, penelitian yang dilakukan oleh (Christiana, 2009) 
juga menyatakan bahwa motivasi belajar siswa sangat penting untuk memperoleh hasil yang lebih baik dalam prestasi belajar siswa. Dengan kata lain, motivasi belajar siswa memiliki korelasi positif yang tinggi dalam prestasi belajar siswa, sehingga dapat disimpulkan bahwa motivasi merupakan kunci keberhasilan dalam prestasi belajar siswa. Hasil penelitian ini juga sekaligus mendukung temuan penelitian sebelumnya yang dilakukan oleh Astuti (2010) yang menunjukkan bahwa terdapat pengaruh motivasi belajar dengan prestasi belajar.

Menurut Hanafiah dan Suhana (2009, p. 26) motivasi belajar merupakan kekuatan (power motivation), daya pendorong (driving force), atau alat pembangun kesediaan dan keinginan yang kuat dalam peserta didik untuk belajar secara aktif, kreatif, inovatif, dan menyenangkan dalam rangka perilaku, baik dalam aspek kognitif, afektif, maupun psikomotor. Motivasi sangat erat hubungannya dan kebutuhan aktualisasi diri, sehingga motivasi paling besar pengaruhnya pada kegiatan belajar siswa untuk mencapai hal yang diharapkan. Ketika siswa tidak memiliki motivasi belajar dalam diri siswa dalam motivasi intrinsik, maka dia akan malas untuk belajar dengan baik, sebab kebab rasa mala situ akan mempengaruhi keberhasilan belajarnya dia. Orang yang mempunyai motivasi yang tinggi dalam belajar maka akan timbul minat yang membangun kebiasaan belajar yang sehat melalui penyusunan jadwal belajar dan melaksanakan dengan tekun.

Pengaruh Keterlibatan Orang Tua, Perilaku Guru, dan Motivasi Belajar terhadap Prestasi Belajar (Pengaruh secara Simultan)

Hasil penelitian ini menunjukkan bahwa terdapat pengaruh keterlibatan orang tua, perilaku guru, dan motivasi belajar secara bersama-sama terhadap prestasi matematika siswa. Temuan penelitian tersebut sejalan dengan hasil Nugraheni (2015) yang menunjukkan bahwa ada pengaruh peran orang tua, motivasi belajar dan lingkungan keluarga terhadap prestasi belajar siswa. Temuan tersebut menunjukkan bahwa semakin baik peran orang tua, motivasi belajar dan semakin baik lingkungan keluarga maka semakin tinggi prestasi belajar siswa.

Prestasi belajar seorang siswa dapat dipengaruh oleh faktor eksternal dan internal. Faktor eksternal dapat berupa keterlibatan orang tua dan perilaku guru, sedangkan faktor internal berasal dari motivasi belajar siswa. Keterlibatan orang tua dalam belajar dapat dilakukan dengan beberapa cara bergantung pada keadaan orang tuanya, antara lain dapat dilihat dari pemberian dukungan terhadap anak, pemberian tambahan bimbingan belajar, pemberian perhatian terhadap tugas sekolah dan jadwal harian, serta ditunjukkan pada keterlibatan orangtua dalam kegiatan sekolah. Apabila cara tersebut dapat dilakukan oleh orang tua bisa dipastikan orang tua terlibat dalam proses belajar anak. Dengan adanya keterlibatan orang tua dalam proses belajar anak, maka hal tersebut dapat memberikan kontribusi terhadap peningkatan prestasi akademik siswa.

Selain faktor keterlibatan orangtua, perilaku guru juga mempengaruhi prestasi belajar siswa. Perilaku guru adalah tingkah laku/sikap guru yang memiliki wawasan keunggulan dengan secara terus menerus mengembangkan ide, gagasan, dan pemikiran terbaik mengenai pembelajaran dan mewujudkannya dalam bentuk perilaku dan sikapnya dalam mengelola proses belajar mengajar sehingga tercipta sistem pembelajaran terbaik bagi siswanya. Jadi guru yang memiliki prilaku seperti itu, akan meningkatkan prestasi belajarnya siswa. Adanya keterlibatan orang tua dan perilaku guru yang baik juga didukung dengan motivasi belajar yang tinggi dapat meningkatkan prestasi belajar. Siswa yang mempunyai motivasi tinggi akan melaksanakan kegiatan belajarnya dengan penuh keyakinan dan tanggung jawab bila dibandingkan dengan siswa yang memiliki motivasi belajar rendah, sehingga akan mencapai prestasi belajar yang optimal. Untuk meningkatkan motivasi belajar, guru dapat menerapkan berbagai model pembelajaran inovatif seperti Problem Based Learning (Amiluddin \& Sugiman, 2016), model Search, Solve, Create, and Share (SSCS) (Satriawan, 2017), Quantum Teaching (Trisnawati \& Wutsqa, 2015), Creative Problem Solving (Apino \& Retnawati, 2017), maupun model-model pembelajaran lainnya.

\section{SIMPULAN}

Berdasarkan hasil penelitian dan pembahasan, maka dapat disimpulkan bahwa keterlibatan orang tua, perilaku guru, dan motivasi belajar masing-masing berpengaruh positif dan signifikan terhadap prestasi belajar matematika siswa kelas X SMA Negeri 4 Yogyakarta tahun ajaran 2016/2017. Selain itu, juga terdapat pengaruh positif dan signifikan keterlibatan orang tua, perilaku guru, dan motivasi belajar secara bersama-sama (simultan) terhadap prestasi belajar matematika siswa kelas X SMA Negeri 
4 Yogyakarta tahun ajaran 2016/2017. Sumbangan besar pengaruh prestasi variabel keterlibatan orang tua, perilaku guru, dan motivasi belajar terhadap prestasi belajar matematika siswa yaitu sebesar 53,9\%, sedangkan sisanya sebesar $46,1 \%$ dipengaruhi oleh faktor lain yang tidak termasuk dalam penelitian ini.

Mengacu pada temuan dalam penelitian ini, terdapat beberapa saran yang dapat dirumuskan. Pertama, orang tua hendaknya meningkatkan perannya dalam mendidik anaknya, melalui sinergi yang dibangun dengan pihak sekolah. Dalam hal ini, sekolah dapat mengambil inisiatif untuk membina hubungan komunikasi yang baik antara guru dan orang tua siswa sehingga tercipta situasi yang mendukung pembelajaran. Orang tua juga disarankan untuk menciptakan lingkungan keluarga yang nyaman dan aman bagi anak-anak, serta memberikan fasilitas belajar di rumah yang baik kepada anak agar dapat meningkatkan prestasi belajar. Kedua, Guru hendaknya senantiasa meningkatkan kemampuan profesionalnya dengan cara membaca buku-buku pengetahuan yang menunjang kegiatan pembelajaran, Senantiasa melakukan inovasi dalam kegiatan pembelajaran, dan meningkatkan semangat dan kedisiplinan dalam bekerja. Langkah-langkah ini diharapkan dapat meningkatkan prestasi belajar siswa. Ketiga, siswa disarankan untuk meningkatkan motivasi belajar dengan cara menumbuhkan rasa suka dan keterikatan pada mata pelajaran matematika, sehingga siswa memiliki kesadaran untuk mempelajari dan memahami mata pelajaran matematika yang akan dan telah disampaikan oleh guru. Keempat, pihak sekolah hendaknya mengadakan pertemuan rutin antara orang tua dan sekolah untuk meningkatkan keterlibatan orang tua guna mendukung aktivitas pembelajaran siswa. Kelima, peneliti selanjutnya agar dapat lebih mengembangkan penelitian ini dengan meneliti faktor lain yang dapat mempengaruhi prestasi belajar serta menggunakan metode lain seperti wawancara, sehingga informasi yang diperoleh lebih bervariasi dibandingkan angket yang jawabannya telah tersedia.

\section{DAFTAR PUSTAKA}

Amiluddin, R., \& Sugiman, S. (2016). Pengaruh problem posing dan PBL terhadap prestasi belajar, dan motivasi belajar mahasiswa pendidikan matematika. Jurnal Riset Pendidikan Matematika, 3(1), 100-108. https://doi.org/10.21831/jrpm.v3i1.7303

Apino, E., \& Retnawati, H. (2017). Developing instructional design to improve mathematical higher order thinking skills of students. In Journal of Physics: Conference Series (Vol. 812). https://doi.org/10.1088/1742-6596/812/1/012100

Astuti, A. E. (2010). Hubungan antara peran orang tua dan motivasi belajar dengan prestasi belajar mata pelajaran sosiologi pada siswa kelas XI SMA Negeri 1 Karangdowo, Klaten Tahun Ajaran 2009/2010. Surakarta: Universitas Sebelas Maret.

Badan Standar Nasional Pendidikan. (2015). Laporan hasil ujian nasional tahun pelajaran 2014/2015 (Vol. 234). Jakarta.

Badan Standar Nasional Pendidikan. (2016). Laporan hasil ujian nasional tahun pelajaran 2015/2016. Jakarta.

Christiana, I. O. (2009). Influence of motivation on students' academic performance. Social Sciences, 4(1), 30-36. Retrieved from http://medwelljournals.com/abstract/?doi=sscience.2009.30.36

Donovan, M. S., \& Bransford, J. D. (2005). How students learn: History in the classroom. Washington D.C.: The National Academies Press. https://doi.org/10.17226/11100

Fung, F., Tan, C. Y., \& Chen, G. (2018). Student engagement and mathematics achievement: Unraveling main and interactive effects. Psychology in the Schools, 55(7), 815-831. https://doi.org/10.1002/pits.22139

Gonida, E. N., \& Cortina, K. S. (2014). Parental involvement in homework: Relations with parent and student achievement-related motivational beliefs and achievement. British Journal of Educational Psychology, 84(3), 376-396. https://doi.org/10.1111/bjep.12039

Hamalik, O. (2010). Kurikulum dan pembelajaran. Jakarta: Bumi Aksara. https://doi.org/2010

Hanafiah, N., \& Suhana, C. (2009). Konsep strategi pembelajaran. Bandung: Refika Aditama.

Jay, T., Rose, J., \& Simmons, B. (2018). Why is parental involvement in children's mathematics learning hard? parental perspectives on their role supporting children's learning. SAGE Open, 8(2). https://doi.org/10.1177/2158244018775466

Komsi, D., Hambali, I., \& Ramli, M. (2018). Kontribusi pola asuh orang tua demokratis, kontrol diri, 
konsep diri terhadap motivasi belajar siswa. Psychology, Evaluation, and Technology in Educational Research, 1(1), 55-61. doi:http://dx.doi.org/10.33292/petier.v1i1.21

Kurniawan, D., \& Wustqa, D. U. (2014). Pengaruh perhatian orangtua, motivasi belajar, dan lingkungan sosial terhadap prestasi belajar matematika siswa SMP. Jurnal Riset Pendidikan Matematika, l(2), 176. https://doi.org/10.21831/jrpm.v1i2.2674

Mehdipour, Y., \& Balaramulu, D. (2013). The influence of teacher's behavior on the academic achievement. International Journal of Advancements in Research \& Technology, 2(5), 217-224.

Muhammad, A. S., Bakar, N. A., Mijinyawa, S. I., \& Halabi, K. A. (2015). Impact of motivation on students' academic performance: A case study of Universiti Sultan Zainal Abidin students. The American Journal of Innovative Research and Applied Sciences, 1(6), 221-226.

Mullis, I. V. S., Martin, M. O., Foy, P., \& Arora, A. (2012). TIMSS 2011 international result in mathematics. Boston, MA: TIMSS \& PIRLS International Study Center. Retrieved from https://timssandpirls.bc.edu/timss2011/downloads/T11_IR_Mathematics_FullBook.pdf

Nugraheni, R. K. (2015). Pengaruh peran orangtua motivasi belajar dan lingkungan keluarga terhadap prestasi belajar siswa kelas III SD se-Gugus Sinduharjo Sleman tahun ajaran 2014/2015. Universitas PGRI Yogyakarta. Retrieved from http://repository.upy.ac.id/138/

OECD. (2016). PISA 2015 results, excellence and equity in education. Pisa (Vol. I). https://doi.org/10.1787/9789264266490-en

Paulpandi, B., \& Govindharaj, P. (2017). Academic achievement in mathematics subject among secondary school students in Madurai, Tamil Nadu. International Journal of Indian Psychology, 4(3), 57-63. https://doi.org/10.25215/0403.108

Rivai, V., \& Murni, S. (2016). Education management: Analisis teori dan praktik. Jakarta: PT Raja Grafindo Persada. Retrieved from http://eprints.radenfatah.ac.id/420/

Satriawan, R. (2017). Keefektifan model search, solve, create, and share ditinjau dari prestasi, penalaran matematis, dan motivasi belajar. Jurnal Riset Pendidikan Matematika, 4(1), 87. https://doi.org/10.21831/jrpm.v4i1.7863

Schunk, D. H., Pintrich, P. R., \& Meece, J. L. (2008). Motivation in education: Theory, research, and applications. New Jersey: Pearson/Merrill Prentice Hall.

Silinskas, G., \& Kikas, E. (2019). Parental involvement in math homework: Links to children's performance and motivation. Scandinavian Journal of Educational Research, 63(1), 17-37. https://doi.org/10.1080/00313831.2017.1324901

Siregar, S. (2010). Statistika deskriptif untuk penelitian. Jakarta: Rajawali Pers.

Slameto, S. (2010). Belajar dan faktor-faktor yang mempengaruhinya. Jakarta: PT Rineka Cipta.

Sugiyono, S. (2015). Metode penelitian pendidikan: Pendekatan kuantitatif, kualitatif, dan $R \& D$. Bandung: Alfabeta.

Sukardi, H. M. (2013). Metode penelitian pendidikan tindakan kelas: Implementasi dan pengembangannya. Jakarta: Bumi Aksara.

Tella, A. (2007). The impact of motivation on student's academic achievement and learning outcomes in mathematics among secondary school students in Nigeria. EURASIA Journal of Mathematics, Science and Technology Education, 3(2), 149-156. Retrieved from http://www.iserjournals.com/journals/eurasia/articles/10.12973/eurasia.2007.00051a

Trisnawati, T., \& Wutsqa, D. U. (2015). Perbandingan keefektifan quantum teaching dan TGT pada pembelajaran matematika ditinjau dari prestasi dan motivasi. Jurnal Riset Pendidikan Matematika, 2(2), 296. https://doi.org/10.21831/jrpm.v2i2.7348

You, S., Dang, M., \& Lim, S. A. (2016). Effects of student perceptions of teachers' motivational behavior on reading, English, and mathematics achievement: The mediating role of domain specific self-efficacy and intrinsic motivation. Child and Youth Care Forum, 45(2), 221-240. https://doi.org/10.1007/s10566-015-9326-x 